\section{PENGELOLAAN SDM UMKM KULINER BINAAN DI CEMPAKA PUTIH \\ JAKARTA PUSAT}

\author{
Dian Riskarini ${ }^{1}$, Lies Putriana ${ }^{2}$, \\ Chaerani $\mathrm{Nisa}^{3}$
}

1,2,3 Fakultas Ekonomi dan Bisnis Universitas Pancasila

\begin{abstract}
Abstrak
UMKM turut memberikan kontribusi terhadap perekonomian Nasional. Namun ternyata sektor ini masih menyimpan beragam kelemahan yang mendasar sehingga kurang dapat berkembang secara optimal. Salah satu kelemahan tersebut bersumber pada belum mampunya UMKM melakukan pengelolaan manajemen SDM dan penerapan fungsi-fungsinya secara baik sehingga kinerja para pelaku UMKM belum dirasakan maksimal. Program Pengabdian kepada Masyarakat yang dilakukan FEBUP bekerjasama dengan PT. Sinar Sosro berupaya mencari solusi atas fenomena yang dihadapi para pelaku UMKM Kuliner Binaan di Cempaka Putih. Melalui wawancara, diskusi dan pemberian pemahaman secara langsung tentang pengelolaan manajemen SDM yang baik maka diharapkan para pelaku UMKM tersebut mampu memahami sekumpulan rencana pengembangan, perbaikan dan evaluasi atas kinerja para pelaku UMKM kuliner tersebut. Dari hasil kunjungan, diskusi dan wawancara langsung ke lapangan tersebut diperoleh hasil kinerja para pelaku UMKM yang belum maksimal seperti pembagian tugas yang masih sederhana, pengadministrasian hasil penjualan yang belum rapih dan pemberian kompensasi yang belum terukur. Diharapkan melalui hasil kegiatan tersebut memberikan manfaat bagi perbaikan pengelolaan manajemen SDM yang berdampak pada peningkatan hasil usaha para pelaku UMKM Kuliner tersebut.
\end{abstract}

Kata Kunci: Pengelolaan SDM, Kinerja Pelaku UMKM

Artikel

Diterima : 1 Juli 2020

Disetujui : 27 Juli 2020

Email:

dianriskarini@univpancasila.ac.id

\begin{abstract}
MSMEs has also contributed to the national economy. However, this sector is unable to develop optimally due to variety of fundamental weaknesses. One of the weaknesses is in regards to Human Resource management and the inability to properly implement its functions which has affected the performance of MSME. Community Service Program was conducted by FEB$U P$ in collaboration with PT. Sinar Sosro in order to find solutions towards the challenges faced by the culinary SMEs in Cempaka Putih Through interviews, discussions and giving direct understanding of good human resource management, we hoped that the MSME actors will be able to understand to make of plans for development, improvement and evaluation of the performance of these culinary MSME actors. From the results of visits, discussions and direct interviews to the field, it was found that the performance of MSME actors was not optimal, such as the simple division of tasks, the administration of sales that was not neat and the provision of compensation that had not been measured. It is hoped that the results of these activities will provide benefits for the improvement of HR management which will have an impact on increasing the business results of these culinary MSMEs.
\end{abstract}

Keywords: HR Management, MSME Performers 


\section{PENDAHULUAN}

UMKM adalah unit usaha produktif yang berdiri sendiri, dilakukan oleh orang perorangan atau badan usaha di semua sektor ekonomi. Pada prinsipnya perbedaan antara Usaha Mikro (UMI), Usaha Kecil (UK), Usaha Menengah (UM) dan Usaha Besar (UB) umumnya didasarkan pada nilai asset awal (tidak termasuk tanah dan bangunan), Omzet rata-rata pertahun atau jumlah pekerja tetap. Hal ini dijelaskan detil pada Undang-Undang Republik Indonesia No. 20 tahun 2008, dengan kriteria sebagai berikut:

a. Usaha Mikro adalah unit usaha yang memiliki asset paling banyak Rp 50 juta tidak termasuk tanah dan bangunan tempat usaha dengan hasil penjualan tahunan paling besar Rp 300 juta.

b. Usaha Kecil adalah usaha dengan asset lebih dari Rp 50 juta sampai dengan paling banyak Rp 500 juta tidak termasuk tanah dan bangunan tempat usaha serta memiliki hasil penjualan tahunan lebih dari Rp 300 juta hingga maksimum Rp2,5 Milyar.

c. Usaha Menengah adalah perusahaan yang memiliki kekayaan bersih lebih dari Rp. 500 juta hingga paling banyak 100 Milyar dengan hasil penjualan tahunan diatas Rp.2,5 Milyar sampai maksimum Rp. 50 Milyar.

UMKM di negara maju adalah kelompok usaha yang mampu menyerap tenaga kerja paling banyak dibandingkan Usaha Besar (UB) dengan kontribusi pada pembentukan atau pertumbuhan Produk Domestik Bruto (PDB) terbesar (Tambunan,2012). UMKM di Indonesia juga memiliki peranan strategis dalam menopang pembangunan ekonomi nasional. Di Era globalisasi ini UMKM dituntut melakukan restrukturisasi dan reorganisasi agar lebih kokoh menumbuhkembangkan potensi serta berdaya tahan tinggi terhadap krisis ekonomi. Hal ini bertujuan untuk memenuhi permintaan konsumen yang semakin spesifik, dinamis, menginginkan produk yang berkualitas namun dengan harga yang terjangkau (Djaddang, Lysandra dan Mulyadi, 2018).

Menurut Sudaryanto (2011), pemberdayaan UMKM di tengah arus globalisasi dan tingginya persaingan membuat UMKM harus mampu menghadapi tantangan global seperti meningkatkan inovasi produk dan jasa, pengembangan sumber daya manusia dan teknologi, serta perluasan area pemasaran. Hal ini perlu dilakukan untuk menambah nilai jual UMKM itu sendiri, utamanya agar dapat bersaing dengan produk-produk asing yang kian membanjiri sentra industri dan manufaktur di Indonesia, mengingat UMKM adalah sektor ekonomi yang mampu menyerap tenaga kerja terbesar di Indonesia.

Kontribusi sektor Usaha Mikro Kecil Menengah (UMKM) terhadap Produk Domestik Bruto (PDB) Indonesia akan terus menjadi ujung tombak pemerintah dalam mendorong perekonomian Indonesia dan hal ini dibuktikan dengan adanya pertumbuhan yang terus menerus. Pemberdayaan UMKM menjadi semakin strategis untuk mendukung peningkatan produktivitas, penyediaan lapangan kerja yang lebih luas serta peningkatan pendapatan masyarakat (Sedyastuti, 2018). Namun, di balik kontribusi UMKM terhadap perekonomian nasional, ternyata sektor ini masih menyimpan banyak kelemahan mendasar yang menyebabkan UMKM belum dapat berkembang maksimal diantaranya 
keterbatasan modal kerja, SDM yang kualitasnya masih rendah serta minimnya penguasaan ilmu pengetahuan dan teknologi (Sudaryanto dan hanim, 2020). Dan Dipta (2008) menyebutkan beberapa kelemahan tersebut antara lain adalah sebagai berikut:

1. Kelemahan dalam akses modal

2. Kelemahan dalam management keuangan

3. Kelemahan dalam mengakses pasar

4. Kelemahan Sumber Daya Manusia (SDM), dan

5. Kelemahan dalam akses teknologi.

Dari beberapa kelemahan yang dimiliki oleh UMKM, kelemahan Sumber Daya Manusia menjadi salah satu masalah yang penting karenanya dalam pengembangan usaha dibutuhkan penataan manajemen Sumber Daya Manusia (SDM) yang baik dan penerapan fungsi-fungsinya agar kinerja para pelaku UMKM bisa menjadi lebih baik. Manajemen SDM merupakan sekumpulan rencana pengembangan, perbaikan dan evaluasi karyawan agar menjadi lebih terukur dan effektif. Dengan kinerja karyawan yang lebih baik maka bisnis yang kecilpun bisa memberikan hasil yang besar.

Manajemen SDM yang baik perlu dipahami oleh para pelaku UMKM karena manusia sebagai salah satu modal dasar di dalam manajemen yang harus dikelola dan terus ditingkatkan kemampuannya. Karena dirasakan penting untuk dipahami dan dijalani, maka sosialisasi dan pendampingan sehubungan dengan perbaikan manajemen sumber daya manusia bagi upaya peningkatan kinerja dan hasil yang diperoleh UMKM dirasakan perlu untuk dilakukan. Salah satu alasan inilah yang mendasari FEB-UP merasa perlu melakukan kegiatan Pengabdian kepada Masyarakat khususnya berkaitan dengan tema Pengelolaan SDM UMKM.

Kegiatan Pengabdian Kepada Masyarakat yang dilakukan oleh tim Fakultas Ekonomi dan Bisnis Universitas Pancasila (FEB-UP) ini dilaksanakan pada tanggal 2 Februaru 2020. Adapun lokasi pelaksanaannya adalah di Pujasera UMKM binaan PT. Sinar Sosro yang beralamat di Jl. Cempaka Putih Tengah I, Jakarta Pusat. Pujasera ini khusus dikelola untuk menampung sekitar 40 pedagang makanan dan minuman kaki lima yang merupakan pedagang binaan baru maupun pedagang binaan lama yang berjualan di sekitar Cempaka Putih. Pujasera binaan PT. Sinar Sosro dan Dinas UMKM DKI Jakarta ini diresmikan oleh PLT. Gubernur DKI Jakarta Bapak Djarot Syaiful Hidayat pada Senin, 21 Mei tahun 2017. Tujuannya adalah dalam upaya penataan lingkungan usaha kuliner yang lebih baik, indah, asri dan nyaman bagi masyarakat.

Secara umum UMKM Kuliner binaan di Cempaka Putih ini belum menerapkan manajemen SDM yang baik. UMKM masih bersifat Income Gathering yaitu suatu usaha dengan tujuan menaikkan pendapatan namun dengan ciri-ciri merupakan usaha milik keluarga, menggunakan teknologi yang masih relative sederhana, kurang memiliki akses permodalan dan belum adanya pemisahan modal usaha dengan kebutuhan pribadi (Sedyastuti, 2018). Manajemen berbasis keluarga dan tanpa adanya evaluasi yang rutin menyebabkan kurang berkembangnya usaha. Selain itu faktor fasilitas dan infrastruktur yang kurang maksimal serta kurang memadai hanya dengan kanopi yang pendek di 
samping trotoar yang hanya cukup menaungi 2 meja bagi para konsumen yang makan ditempat. Untuk bisa mendukung operasionalisasi usaha harian UMKM Kuliner tersebut hal ini dirasa masih sangat kurang maksimal dan memberikan kenyamanan. Lokalisasi yang dibangun kurang luas dengan kanopi yang sangat terbatas hanya mampu menaungi tidak lebih dari 2 meja Panjang yang masksimal mampu menampung 10 orang pelanggan yang makan ditempat. Ketidaknyamanan bagi para pelanggan akan dirasakan lebih bila cuaca terasa sangat terik atau hujan terjadi. Hal ini dikarenakan kanopi tidak mampu memberikan manfaat maksimal karena pelanggan masih dapat merasakan panasnya terik matahari ataupun terkena air hujan.

Sejauh ini, pembagian tugas sederhana telah diterapkan namun perekrutan karyawan belum dilakukan secara benar, hanya berdasarkan ketersediaan dana untuk kecukupan membayar pegawai saja. Jika dirasa pendapatan tidak maksimal maka perekrutan karyawanpun tidak dilakukan dan cukup dengan melibatkan unsur keluarga inti saja. Karena secara umum masih melibatkan unsur keluarga saja, maka pemberian kompensasipun dilakukan secara sederhana dengan sifat harian. Evaluasi rutin juga belum dilakukan dengan baik dan benar karena sebagian besar tidak melakukan pencatatan atas pemasukan dan pengeluaran harian yang terjadi. Aturan dan prosedur yang diterapkan masih bersifat kompromistis sesuai dengan kondisi internal keluarga ataupun pemilik UMKM.

Tujuan dari pelaksanaan kegiatan Pengabdian kepada Masyarakat ini adalah pencapaian target yang diharapkan yaitu meningkatnya pemahaman para pelaku UMKM atas penerapan pengelolaan manajemen SDM bagi usahanya. Melalui upaya rencana pengembangan, pembagian tugas, perbaikan dan evaluasi kinerja karyawan serta perolehan hasil harian yang dibuat dalam pelaporan sebagai bentuk monitoring kemajuan usaha.

Adapun manfaat kegaitan ini bagi pemerintah daerah DKI Jakarta adalah berkurangnya tingat pengangguran dan kesenjangan sosial, meningkatnya kualitas sumber daya manusia serta meningkatnya pertumbuhan ekonomi dan PAD. Sedangkan manfaat bagi para Dosen FEB-UP adalah dapat memberikan kontribusi kepada masyarakat sekitar dan menjalankan fungsi Tri Dharma Perguruan Tinggi di bidang Pengabdian kepada Masyarakat. Selain itu, kegiatan ini akan memberikan nilai tambah pada FEB-UP khususnya dan civitas akademika Universitas Pancasila pada umumnya. Sementara bagi PT. Sinar Sosro sebagai Perusahaan yang melakukan upaya pembinaan sebagai bagian dari pelaksanaan kegiatan Corporate Social Responsibility (CSR). PT. Sinar Sosro berupaya melakukan perbaikan-perbaikan dari sisi penyediaan fasilitas, pelaksanaan program-program pengembangan ketrampilan masyarakat serta pemantauan dan evaluasi pencapaian hasil atas upaya pembinaan yang dilakukan sekaligus upaya mempromosikan beragam produk yang dihasilkan Sosro.

\section{METODE}

Metode pelaksanaan Pengabdian kepada Masyarakat di Pujasera UMKM Cempaka Putih Jakarta Binaan PT. Sinar Sosro dilakukan melalui 3 tahapan yaitu:

1. Tahap persiapan 
a. Melakukan koordinasi dengan pihak PT.Sinar Sosro sebagai mitra Kerjasama Pengabdian kepada Masyarakat dengan menentukan lokasi UMKM Binaan.

b. Melakukan survei awal ke lokasi mitra binaan untuk pemantapan rencana pelaksanaan sekaligus mengetahui permasalahan UMKM binaan secara umum.

2. Tahap pelaksanaan.

a. Tim FEBUP Melakukan Kunjungan Lapangan ke lokasi Pujasera sebagai UMKM Kuliner binaan PT. Sinar Sosro pada tanggal 2 Februari 2020.

b. Wawancara dengan pemilik UMKM untuk mengetahui apakah telah dilakukan Pengelolaan SDM seperti pembagian kerja yang didukung dengan perolehan kompensasi yang wajar.

c. Berdiskusi dengan para pelaku UMKM untuk mengetahui Riwayat, permasalahan dasar, harapan dan langkah-langkah solusi yang diinginkan pelaku UMKM.

d. Menanyakan pada pemilik UKM tentang upaya pencatatan/pelaporan atas modal harian yang dikeluarkan dan pendapatan atas hasil usaha setiap harinya. Berupaya menyarankan perlunya kedisiplinan untuk pembuatan laporan harian sebagai upaya melihat tingkat produktivitas usaha.

e. Menanyakan perihal adanya keluhan dan saran dari konsumen. Menyarankan upaya komunikasi yang baik bagi pemecahan masalah yang ditemukan termasuk dalam menanggapi masukan pelanggan dan menawarkan produk yang dijual.

f. Memberikan penyuluhan dengan menambah wawasan dan motivasi mengenai pentingnya upaya pemgelolaan SDM, peningkatan keterampilan serta service bagi karyawan UKM.

3. Tahap Evaluasi

a. Memberikan arahan/masukan dan petunjuk bagaimana melakukan rencana perbaikan dan evaluasi kinerja karyawan agar lebih baik dalam bekerja.

b. Melakukan evaluasi kajian sebagai bahan bagi peneliti serta program pengabdian kepada masyarakat lanjutan yang bermanfaat bagi pengembangan UMKM binaan tersebut.

Memberikan masukan bagi mitra Pengabdian kepada Masyarakat (PT. Sinar Sosro) tentang kondisi manajemen pengelilaan SDM para pelaku UMKM binaannya.

\section{HASIL \& PEMBAHASAN}

Di dalam kerangka ekonomi daerah, pembangunan ekonomi daerah dan masyarakat mengelola sumberdaya-sumberdaya yang ada dan membentuk suatu pola kemitraan antara pemerintah daerah dengan sektor swasta untuk menciptakan lapangan kerja baru yang sekaligus menjadi stimulus terhadap perkembangan ekonomi daerah (Arsyad, 2014). Untuk mencapai tujuan pembangunan daerah kebijakan yang dikeluarkan harus bertumpu pada potensi dari masing-masing daerah tersebut. Di Provinsi DKI Jakarta pengelolaan sumberdaya masyarakat melalui pemberdayaan UMKM di bawah pengawasan Dinas Koperasi dan UMKM juga bermitra dengan CSR perusahaan swasta yang peduli 
pada kesejahteraan masyarakat. Pengelolaan sumberdaya masyarakat yang dituju salah satunya adalah peningkatan mutu manajemen SDM para UMKM.

Salah satu cara mencapai tujuan pengembangan usaha diperlukan pengelolaan manajemen SDM bagi UKM yang baik dan terarah. Terdapat 6 langkah penting dalam manajemen SDM untuk Kesuksesan UMKM (Gray, 2002), antara lain :

1. Menyusun Struktur Organisasi UMKM, dengan pembagian tugas antar personil yang terlibat.

2. Memulai Proses Seleksi dan Rekrutmen anggota baru sesuai dengan keahlian yang dibutuhkan.

3. Mengagendakan Pelatihan dan Pengembangan untuk semua karyawan yang terlibat dalam UMKM.

4. Membuat Aturan, Prosedur dan Kebijakan Kerja.

5. Memberikan Gaji/Kompensasi yang Wajar dan sesuai, dan

6. Melakukan Evaluasi dan pencatatan manajemen SDM secara berkala.

Berdasarkan ketiga tahapan pelaksanaan pengabdian kepada masyarakat di Pujasera Yarsi sebagai bagian dari UMKM Binaan PT. Sinar Sosro yang berada pada bidang kuliner, maka diperoleh beberapa hasil wawancara sebagai berikut:

Tabel 1. Hasil Wawancara/Observasi

\begin{tabular}{|c|c|c|}
\hline No & Nama UMKM & Hasil Wawancara \\
\hline 1 & $\begin{array}{l}\text { UMKM Kuliner Warung } \\
\text { Nasi Asniar }\end{array}$ & 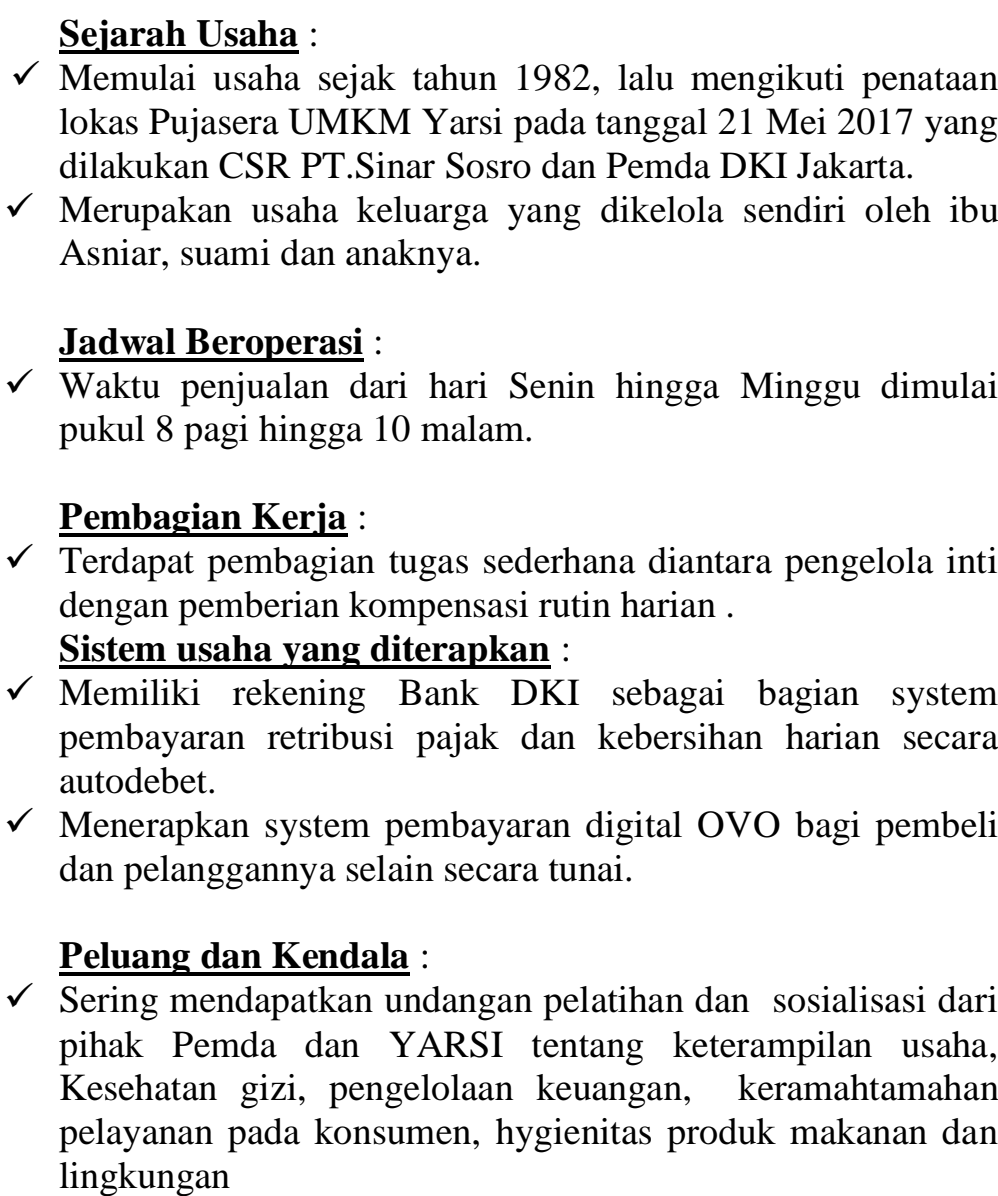 \\
\hline
\end{tabular}




\begin{tabular}{|c|c|c|}
\hline & & $\begin{array}{l}\text { Monitoring dan Evaluasi yang rutin dilakukan oleh Lakesda } \\
\text { Dinas UMKM Provinsi DKI Jakarta yaitu mengecek } \\
\text { kandungan pemakaian bahan-bahan berbahaya pada } \\
\text { makanan yang dijual seperti Formalin, Borax serta Pengawet } \\
\text { berbahaya pada semua makanan yang dijual. Disertai } \\
\text { pemberlakuan sanksi teguran dan penutupan pada UMKM } \\
\text { yang bermasalah. } \\
\checkmark \text { Terdapat beberapa kendala seperti kurangnyamannya } \\
\text { fasilitas infrastruktur kanopi warung usaha, keterbatasan } \\
\text { pendapatan / modal yang berimbas pada minimnya upaya } \\
\text { perekrutan karyawan untuk membantu pelayanan usaha. }\end{array}$ \\
\hline 2 & $\begin{array}{l}\text { UMKM Kuliner Warung } \\
\text { Nasi Fajar }\end{array}$ & $\begin{array}{l}\text { Sejarah Usaha : } \\
\text { Berdiri sejak tahun } 1989 \text { kemudian sempat dibongkar pada } \\
\text { tahun } 2015 \text { untuk kemudian dibangun lagi pada tahun } 2016 . \\
\checkmark \text { Mulai bekerja sama dengan Sosro sebagai partner dalam } \\
\text { menyediakan berbagai minuman ringan dan pembuatan } \\
\text { infrastruktur kios sejak tahun } 2016 \text { yang diresmikan pada } \\
\text { tahun } 2017 \text { oleh Pemda DKI Jakarta. } \\
\checkmark \text { Menjual aneka masakan rumahan seperti nasi dan lauk pauk } \\
\text { serta aneka minuman segar. } \\
\text { Pembagian Kerja : } \\
\text { Terkait dengan pembagian kerja, Bapak Pujianto melakukan } \\
\text { pembagian dengan melihat ketersediaan waktu pada masing- } \\
\text { masing anggota keluarganya yang sekaligus berperan } \\
\text { sebagai pegawai pada kios. Namun untuk kegiatan memasak } \\
\text { makanan lauk biasanya dilakukan oleh Ibu Kus. Pembagian } \\
\text { pengelolaan warung biasanya yang menjaga warung nasi } \\
\text { adalah Pak Puji dan Bu Kus. } \\
\checkmark \text { Jadwal Beroperasi: } \\
\text { Untuk membuka warung dan menutup warung biasanya } \\
\text { dilakukan secara bergantian karena jam buka kedua warung } \\
\text { cukup panjang yaitu buka pada pukul } 6 \text { pagi dan baru tutup } \\
\text { pada pukul 11 malam. } \\
\checkmark \text { Sistem Usaha yang diterapkan: } \\
\checkmark \text { Memberikan fasilitas delivery kepada pelanggannya dengan } \\
\text { memberikan nomor telfon yang bisa dihubungi untuk } \\
\text { pemesanan makanan. } \\
\checkmark \text { Memiliki rekening Bank DKI sebagai bagian system } \\
\text { pembayaran retribusi pajak dan kebersihan harian secara } \\
\text { autodebet. } \\
\text { Peluang dan Kendala : } \\
\text { Mendapatkan berbagai jenis pelatihan dari dosen Universitas } \\
\text { Yarsi. Pelatihan tersebut diantaranya adalah pelatihan } \\
\text { pembuatan laporan keuangan, kebersihan ruangan dan cara } \\
\text { melayani pelanggan. } \\
\text { Mengikuti program monitoring dan evaluasi yang dilakukan } \\
\text { meh Lakesda Dinas UMKM Provinsi DKI Jakarta yaitu } \\
\text { pada makanan yang dijual seperti Formalin, Borax serta } \\
\text { Pengawet berbahaya pada semua makanan yang dijual. }\end{array}$ \\
\hline
\end{tabular}




\begin{tabular}{|c|c|c|}
\hline & & $\begin{array}{l}\text { Disertai pemberlakuan sanksi teguran dan penutupan pada } \\
\text { UMKM yang bermasalah. } \\
\checkmark \text { Tidak adanya follow up dan monitoring dari beberapa jenis } \\
\text { pelatihan secara berkelanjutan }\end{array}$ \\
\hline 3 & $\begin{array}{l}\text { UMKM Kuliner Kios } \\
\text { Makanan Tepi Jalan }\end{array}$ & $\begin{array}{l}\text { Sejarah Usaha: } \\
\checkmark \text { Kios ini mulai berdiri sejak tahun } 1989 \text { dan sempat } \\
\text { dibongkar pada tahun } 2015 \text { untuk kemudian dibangun lagi } \\
\text { pada tahun 2016. Dengan adanya pembuatan infrastruktur } \\
\text { kios sejak tahun } 2016 \text { yang diresmikan pada tahun } 2017 \text { oleh } \\
\text { Pemda DKI Jakarta berlokasi di Pujasera Yarsi Cempaka } \\
\text { Putih Jakarta. } \\
\checkmark \text { Kios makanan Tepi Jalan dimiliki juga oleh suami isteri } \\
\text { Bapak Pujianto dan Ibu Kus, namun pengelolaan warung } \\
\text { dibantu oleh kedua anaknya yaitu Fajar dan Anto. } \\
\checkmark \text { Kios makanan Tepi Jalan menjual makanan seperti nasi } \\
\text { goreng, mie goreng, mie rebus dan lainnya. } \\
\checkmark \text { Pembagian Kerja : } \\
\text { Pengelolaan kios makanan oleh kedua putra pak Pujianto dan } \\
\text { bu Kus yaitu Fajar dan Anto dengan Pembagian tugas } \\
\text { bersifat fleksibel dilihat dari kesediaan waktu kedua } \\
\text { putranya. } \\
\checkmark \text { Sistem usaha yang diterapkan: } \\
\text { Memiliki rekening Bank DKI sebagai bagian system } \\
\text { pembayaran retribusi pajak dan kebersihan harian secara } \\
\text { autodebet. } \\
\checkmark \text { Hanya melayani makan di tempat. } \\
\checkmark \text { Peluang dan Kendala: } \\
\text { Rutin di evaluasi dan dimonitor terkait penggunaan bahan- } \\
\text { bahan makanan berbahaya untuk menjaga kualitas dan } \\
\text { kandungan makanan yang dilakukan oleh Lakesda dinas } \\
\text { UMKM Pemda Provinsi DKI Jakarta. } \\
\checkmark \text { Fasilitas Kanopi yang sempit dan kurang menaungi } \\
\text { pelanggan dari panas dan hujan. }\end{array}$ \\
\hline 4 & $\begin{array}{l}\text { UMKM Kuliner Warung } \\
\text { Kopi Starbak }\end{array}$ & $\begin{array}{l}\checkmark \text { Sejarah Usaha : } \\
\text { Warung Kopi dan Indomie Starbak milik Ari ini termasuk } \\
\text { dalam pedagang lama yang menjajakan dagangannya di } \\
\text { wilayah Cempaka Putih Jakarta Pusat. } \\
\checkmark \text { Warung ini sudah ada sejak } 1989 \text { dan ikut menjadi pedagang } \\
\text { kuliner binaan sejak adanya relokasi dan perbaikan fasilitas } \\
\text { pedagang kaki lima yang disponsori oleh PT. Sinar Sosro } \\
\text { sejak tahun } 2017 \text { yang lalu. } \\
\checkmark \text { Warung ini menjual aneka minuman panas dan dingin seperti } \\
\text { kopi, susu dan es jeruk. Selain itu menjual juga beragam } \\
\text { jenis olahan mie instan dan telur setengah matang serta } \\
\text { aneka makanan ringan. } \\
\checkmark \\
\text { Pembagian Kerja : } \\
\text { Terkait dengan pembagian kerja, Ari melakukan pembagian } \\
\text { kerja pada ketiga karyawannya juga sekaligus berperan ikut } \\
\text { menjaga pada kios. }\end{array}$ \\
\hline
\end{tabular}




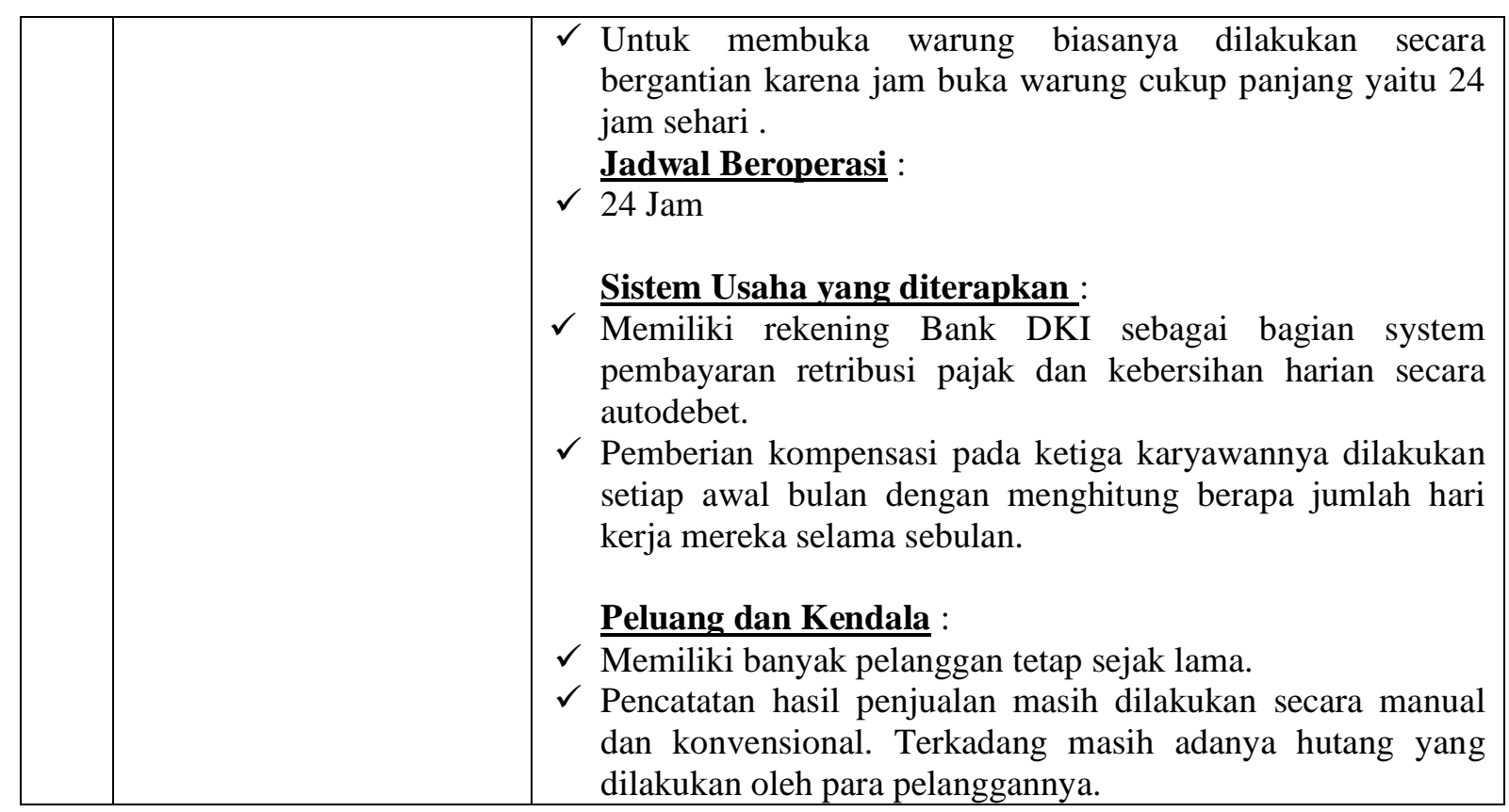

Adapun tindak lanjut kegiatan Pengabdian kepada Masyarakat ini adalah merencanakan melakukan pemetaan potensi UMKM dengan kriteria sebagai berikut:

1. Nama UMKM

2. Nama Pemilik/Pengelola

3. Fokus Usaha Kuliner

4. Lama Usaha

5. Aktifitas Manajemen yang telah diterapkan

6. Aktifitas manajemen yang belum diterapkan

7. Pembinaan yang dilakukan CSR dan Pemerintah

8. Harapan ke depan bagi perbaikan UMKM binaan

Selanjutnya juga menerapkan kegiatan pemantauan dan evaluasi lanjutan persemester untuk melihat perkembangan hasil usaha dengan time table sebagai berikut:

MONITORING KEGIATAN UMKM TAHUN 2020/2021

\begin{tabular}{|c|c|c|c|c|c|c|c|c|c|c|c|c|c|}
\hline \multirow[t]{2}{*}{ No } & \multirow[t]{2}{*}{ Monitoring } & \multicolumn{12}{|c|}{ JADWAL (BULAN) } \\
\hline & & 1 & 2 & 3 & 4 & 5 & 6 & 7 & 8 & 9 & 10 & 11 & 12 \\
\hline 1. & Pelaksanaan Kegiatan & & & & & & & & & & & & \\
\hline 2. & Waktu Kegiatan UMKM & & & & & & & & & & & & \\
\hline 3. & $\begin{array}{l}\text { Pelaksanaan Uraian Tugas Personil } \\
\text { UMKM }\end{array}$ & & & & & & & & & & & & \\
\hline 4. & $\begin{array}{l}\text { Kesesuaian Pengelolaan dan } \\
\text { Pelaksanaan UMKM terhadap SOP } \\
\text { yang diterapkan Pemda \& CSR }\end{array}$ & & & & & & & & & & & & \\
\hline 5. & \begin{tabular}{llr} 
Kesesuaian & \multicolumn{2}{l}{ Pengelolaan } \\
Pelaksanaan & UMKM & terhadap \\
Rencana Usaha & &
\end{tabular} & & & & & & & & & & & & \\
\hline
\end{tabular}


Melalui upaya pemetaan dan penjadwalan monitoring tersebut diharapkan dapat memberikan masukan bagi mitra Pembina UMKM baik Dinas UMKM Provinsi DKI Jakarta maupun PT. Sinar Sosro atas harapan-harapan para UMKM Pujasera Yarsi sehingga diketahui permasalahan dan solusi yang bisa dilakukan di kemudian hari.

Berikut ini adalah beberapa hasil dokumentasi pelaksanaan kegiatan Pengabdian kepada Masyarakat yang dilakukan di Pujasera UMKM Yarsi oleh Tim Fakultas Ekonomi dan Bisnis Universitas Pancasila:

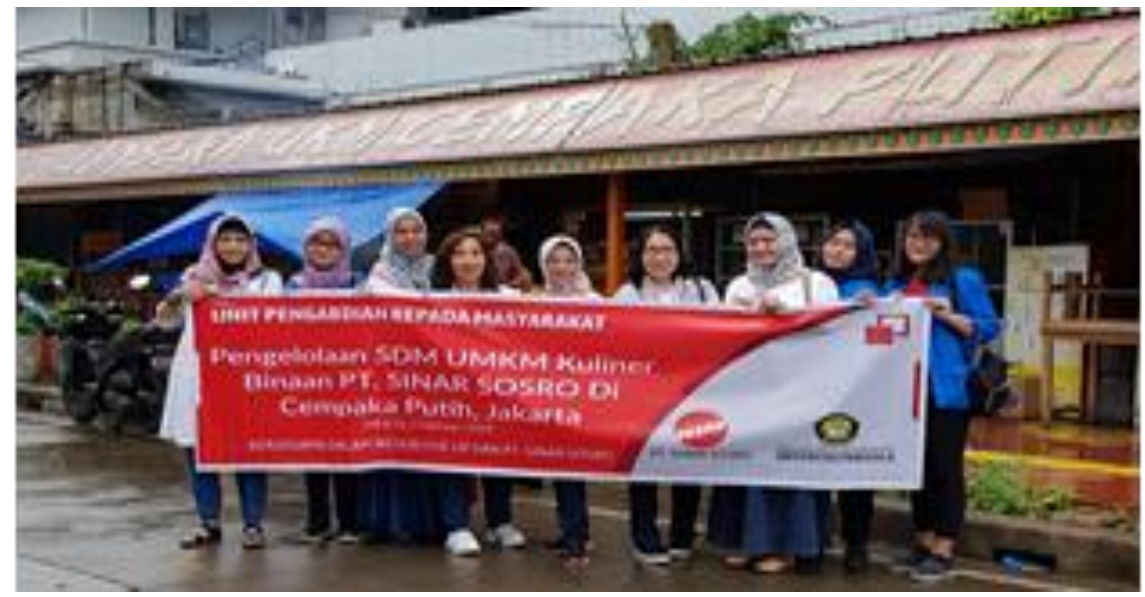

Gambar 1. Tim Abdimas Pengelolaan SDM bagi UMKM Pujasera Yarsi

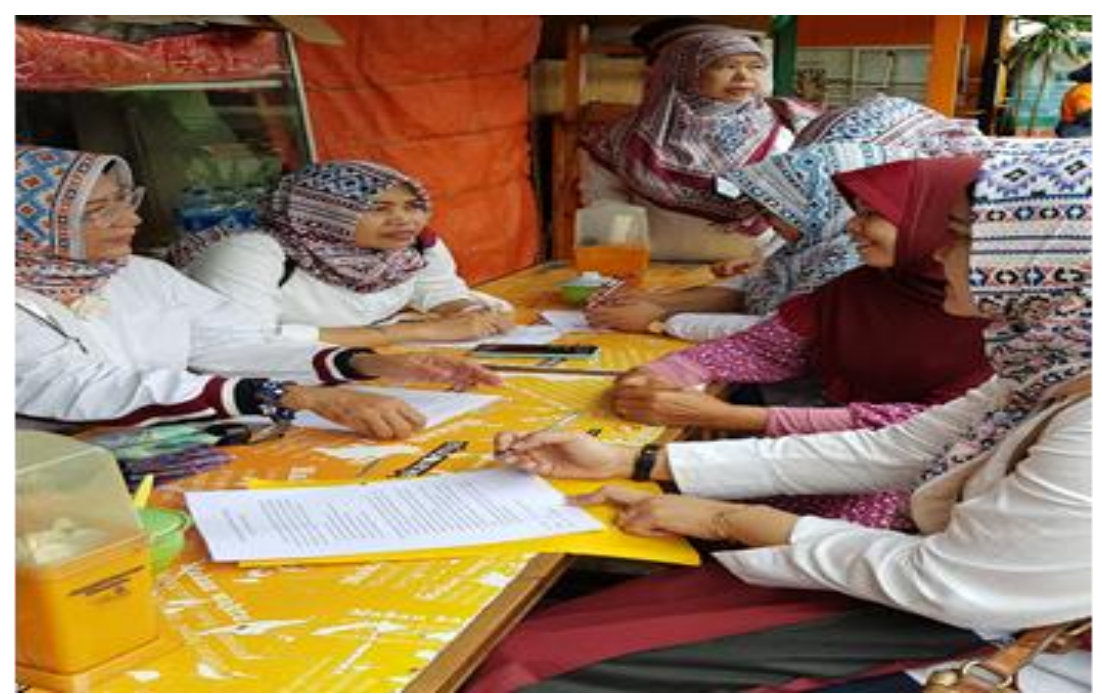

Gambar 2. Kegiatan Penyuluhan dan Pemberian arahan tentang Pengelolaan SDM pada pelaku UMKM 


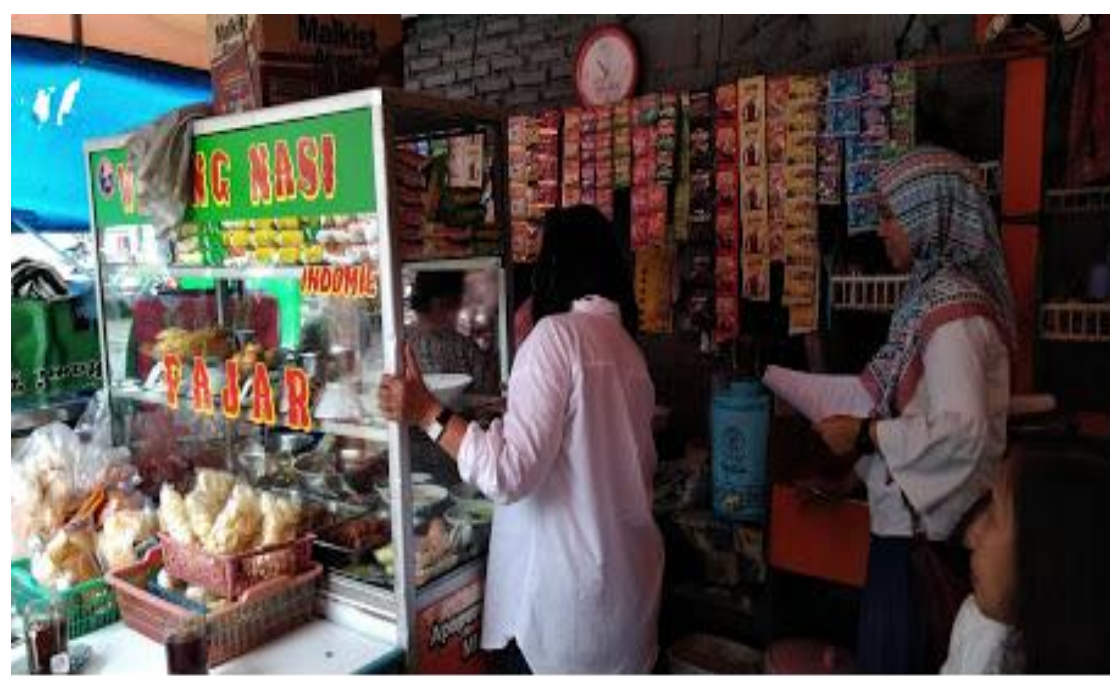

Gambar 3. Kegiatan Wawancara pada Pelaku UMKM

\section{SIMPULAN}

\section{Kesimpulan}

Secara umum beberapa fakta yang ditemukan berdasarkan hasil observasi dan wawancara terhadap beberapa UMKM Pujasera Yarsi antara lain:

1. Merupakan pedagang lama yang telah ada dan berdagang sejak tahun 1989.

2. Pembagian tugas sederhana telah diterapkan namun perekrutan karyawan belum dilakukan secara benar karena secara umum masih melibatkan unsur keluarga saja dengan alasan keterbatasan biaya untuk bisa menggaji karyawan secara wajar.

3. Para pedagang kuliner di pujasera tersebut belum menerapkan pelaporan dan evaluasi kerja setiap harinya. Evaluasi rutin juga belum dilakukan dengan baik dan benar karena sebagian besar tidak melakukan pencatatan atas pemasukan dan pengeluaran harian yang terjadi.

4. Aturan dan prosedur yang diterapkan masih bersifat kompromistis sesuai dengan kondisi internal keluarga ataupun pemilik UMKM.

5. Telah dirasakan beragam upaya peningkatan keterampilan dan pengetahuan yang sebagian besar mereka terima dari undangan sosialisasi dan pelatihan yang dilakukan oleh pihak YARSI dan pemerintah DKI Jakarta melalui Sudin UMKM.

6. Monitoring dan evaluasipun rutin dilakukan oleh pihak pemerintah melalui Lakesda Dinas UMKM dalam upaya menjaga higienitas dan mutu makanan yang dijual agar bebas dari kandungan bahan makanan yang berbahaya seperti formalin, borax, zat pewarna maupun pengawetberbahaya lainnya.

7. Tim pengabdian Pengelolaan SDM FEB-UP memberikan materi/arahan kepada pedagang UKM kuliner tentang bagaimana merencanakan pengembangan, perbaikan dan evaluasi karyawan 
agar lebih baik lagi sehingga walau melakukan bisnis sederhana tetap bisa memberikan hasil yang maksimal.

\section{Saran}

Berdasarkan hasil observasi lapangan dan kajian atas kesimpulan hasil diskusi dengan para pelaku UMKM Pujasera binaan di Cempaka Putih maka beberapa hal yang bisa dijadikan saran membangun bagi kegiatan pengabdian kepada masyarakat selanjutnya antara lain:

1. Setiap bentuk pelatihan maupun sosialisasi kepada para pelaku UMKM hendaknya disertai dengan Tindakan monitoring berkesinambungan setidaknya dalam kurun waktu tiga atau enam bulan sekali agar para pelaku UMKM tidak terlupa terkait hasil pelatihan maupun sosialisasi ilmu baru yang telah mereka dapatkan.

2. Membantu mewujudkan harapan pelaku UMKM melalui kemitraan agar bisa mendapatkan pembiayaan untuk memperluas bidang usaha dan menambah pegawai yang memiliki keahlian sehingga bisa meningkatkan penerimaan.

3. Bagi UMKM, perlu melakukan Evaluasi manajemen SDM rutin, pelaporan tertulis secara berkala serta membuat kebijakan kerja yang lebih efektif dan efisien.

4. Bagi PT. Sinar Sosro sebagai mitra Pembina, perlu Penambahan infrastuktur yang lebih memberikan kenyamanan lokasi pujasera bagi para pelaku UMKM maupun bagi konsumen pelanggan pujasera binaan di Cempaka Putih seperti perluasan Kanopi warung dan penambahan meja serta tempat duduk bagi pelanggan yang ingin makan ditempat.

\section{DAFTAR PUSTAKA}

Dipta, I Wayan, 2008. Strategi Penguatan Usaha Mikro, Kecil dan Menengah (UMKM) melalui Kerjasama Kemitraan Pola CSR. INFOKOP Volume. 16, September 2008.

Djaddang, S., Lysandra, S. dan Mulyadi. (2018). Peran Entrepreneur-Orientation Terhadap Volatilitas UKM Dengan Budaya Lokal Sebagai Pemediasi, Jurnal Riset Bisnis Vol. 2 (1), 21-31.

Gray, C. 2002. Entrepreneurship, resistance to change and growth in small firms. Journal of Small Business and Enterprise Development. Vol. 9, No.1, p: 61-72.

Sedyastuti, K. 2018. "Analisis Pemberdayaan UMKM dan Peningkatan Daya Saing Dalam Kancah Pasar Global", INOBIS: Jurnal Inovasi Bisnis dan Manajemen Indonesia, Volume 2, Nomor 1, Desember 2018.

Sudaryanto dan Hanim, Anifatul. 2002. Evaluasi Kesiapan UKM Menyongsong Pasar Bebas Asean (AFTA): Analisis Perspektif dan Tinjauan Teoritis. Jurnal Ekonomi Akuntansi dan Manajemen, Vol 1 No.2, Desember 2002.

Sudaryanto. 2011. The Need for ICT-Education for Manager or Agribusinessman to Increasing Farm Income: Study of Factor Influences on Computer Adoption in East Java Farm Agribusiness. International Journal of Education and Development, JEDICT, Vol 7 No 1 halm. 56-67.

Tulus Tambunan. 2012. Usaha Mikro Kecil dan Menengah di Indonesia : Isu-isu Penting, Jakarta, LP3ES.

Undang-Undang Repunlik Indonesia No. 20 Tahun 2008 Tentang Usaha Mikro Kecil menengah (UMKM) 